Elsevier

GENE 03284

\title{
The P2 phage old gene: sequence, transcription and translational control
}

(Bacteriophage; codon usage; plasmid; promoter; recombinant DNA; tRNA)

\author{
Elisabeth Haggård-Ljungquist ${ }^{a}$, Virginia Barreiro ${ }^{a}$, Richard Calendar ${ }^{b}$, David M. Kurnit ${ }^{c}$ and Hans Cheng ${ }^{b}$ \\ ${ }^{a}$ Department of Microbial Genetics, Karolinska Institutet, S-10401 Stockholm 60 (Sweden); ${ }^{b}$ Department of Molecular and Cell \\ Biology, Wendell M. Stanley Hall, University of California, Berkeley, CA 94720 (U.S.A.) Tel. (415)642-5951 and ${ }^{c}$ Howard \\ Hughes Medical Institute, University of Michigan, Ann Arbor, MI 48109 (U.S.A.) Tel. (313)747-4747
}

Received by Y. Sakaki: 18 April 1989

Revised: 15 June 1989

Accepted: 17 July 1989

\section{SUMMARY}

The old (overcoming lysogenization defect) gene product of bacteriophage P2 kills Escherichia coli recB and rec $C$ mutants and interferes with phage $\lambda$ growth [Sironi et al., Virology 46 (1971) 387-396; Lindahl et al., Proc. Natl. Acad. Sci. USA 66 (1970) 587-594]. Specialized transducing $\lambda$ phages, which lack the recombination region, can be selected by plating $\lambda$ stocks on $E$. coli that carry the old gene on a prophage or plasmid [Finkel et al., Gene 46 (1986) 65-69]. Deletion and sequence analyses indicate that the old-encoded protein has an $M_{\mathrm{r}}$ of 65373 and that its transcription is leftward. Primer extension analyses locate the transcription start point near the right end of the virion DNA. A bacterial mutant, named pin 3 and able to suppress the effects of the old gene, has been isolated [Ghisotti et al., J. Virol. 48 (1983) 616-626]. In a pin3 mutant strain, carrying the old gene on a prophage or plasmid, the amount of old transcript is greatly reduced. The effect of the pin 3 mutation is abolished by the wild-type allele of $\arg U$, an arginine tRNA that reads the rare Arg codons AGA and AGG, which are used for eight of the $14 \mathrm{Arg}$ codons in the old gene. Thus the pin 3 allele probably stalls translation of the old mRNA, causing this mRNA to be degraded. Isoelectric focusing and electrophoretic analysis identify the old gene product as a basic protein of approx. $65 \mathrm{kDa}$.

\section{INTRODUCTION}

Temperate coliphage $\mathrm{P} 2$ encodes a gene called old that causes killing of $E$. coli $r e c B$ and $r e c C$ mutants

Correspondence to: Dr. E. Haggård-Ljungquist, Department of Microbial Genetics, Karolinska Institutet, Box 60400, S-10401 Stockholm (Sweden) Tel. (46-8) 7287338; Fax (08)339380; and to: Dr. R. Calendar, Department of Molecular and Cell Biology, Wendell M. Stanley Hall, University of California, Berkeley, CA 94720 (U.S.A.) Tel. (415)642-5951; Fax (415)643-9290.
(Sironi, 1969) and interferes with the growth of phage $\lambda$ (Lindahl et al., 1970). Interference with $\lambda$ growth involves the inhibition of $\lambda$ late gene expression and the inhibition of $E$. coli RNA and protein 
synthesis (Sironi et al., 1971). The old gene product requires the $E$. coll pin ( $P 2$ interference) genes for its action (Ghisotti et al., 1983). The first $\lambda$ mutants selected for their ability to make plaques in a P2-lysogenic strain were $\lambda$ bio transducing phages. They had lost their gam gene, which is responsible for inacti- vating recBC nuclease (Karu et al., 1975), and their recombination genes exo and $\beta$ (Zissler et al., 1971). Selection for genetically engineered $\lambda$ transducing phages is often performed by plating on $E$. coli that carries P2 prophage (Murray, 1983) or the P2 old gene on a plasmid (Finkel et al., 1986). To be able to
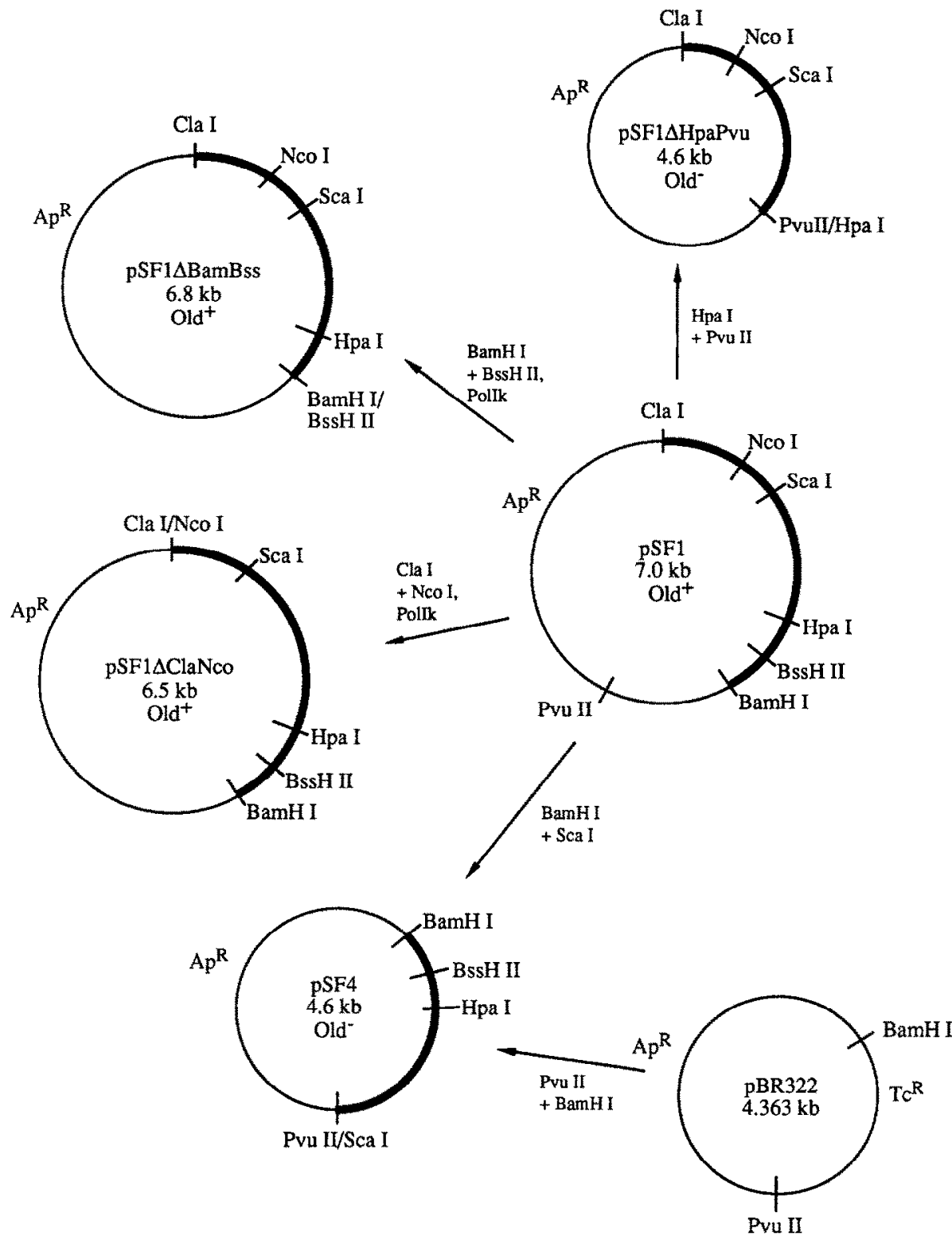

Fig. 1. Plasmids containing deletions of the old region. The Old ${ }^{+}$phenotype was determined by interference with $\lambda$ phage growth as described by Finkel et al. (1986). The thin lines represent DNA from plasmids, whereas the thick lines are DNA from P2 phage. Plasmid pBR322 is described by Bolivar et al. (1977); pSF1 is described by Finkel et al. (1986). Deletions of pSF1 were constructed as follows. Cleavage with $\mathrm{HpaI}+$ PvuII followed by ligation yielded pSF1 $\Delta \mathrm{HpaPvu}$. Cleavage with $B a m \mathrm{HI}+$ Bss HII was followed by filling-in with Pollk (Jacobsen et al., 1974) and ligation, to give pSF1 1 BamBss. Cleavage with $\mathrm{ClaI}+\mathrm{NcoI}$, followed by filling and ligation yielded pSF1 14 ClaNco. pSF1 was cleaved with BamHI + ScaI; the fragment containing only P2 DNA was purified by electrophoresis in low melting agarose and was ligated to the large fragment of pBR322 cut with BamHI + PvuII, to give pSF4. Plasmid pUC18 (Norrander et al., 1983) was used as the vector for nt sequence analysis. 
clone the old gene more precisely, to overproduce its product and to study its mechanism of action, we have determined its location by deletion and sequence analyses and have identified the old gene product.

\section{RESULTS AND DISCUSSION}

\section{(a) Deletion analysis}

To locate the old gene more precisely we deleted DNA from the plasmid pSF1, which contains an active old gene in a 3-kb ClaI-Bam $\mathrm{HI}$ fragment of $\mathrm{P} 2$ DNA (Figs. 1 and 2). We deleted $500 \mathrm{bp}$ from the left side using $\mathrm{NcoI}$ without loss of the $\mathrm{Old}^{+}$phenotype. When we removed another $650 \mathrm{bp}$ from the left side using $\mathrm{ScaI}$ we lost the $\mathrm{Old}^{+}$phenotype. From the right side of the P2 DNA fragment we deleted
240 bp using Bss HII without loss of the $\mathrm{Old}^{+}$phenotype. Removal of $700 \mathrm{bp}$ from the right side using HpaI destroyed the Old ${ }^{+}$phenotype. Thus all of the old gene lies between the $\mathrm{NcoI}(93.1 \%)$ and Bss HII $(100 \%)$ sites. The ScaI $(95.1 \%)$ and $\mathrm{HpaI}(98.6 \%)$ sites must lie within the old gene.

\section{(b) Sequence analysis}

As shown in Figs. 2 and 3, the NcoI-Bss HII region contains only one long ORF, going from right to left on the P2 genetic map. It begins at nt 214 with an AUG start codon and ends at nt 1971 with an ochre stop codon, giving a polypeptide of 586 aa. The AUG codon is preceded by a potential RBS (Steitz and Jakes, 1975) centered 9 nt upstream from the start codon, and as the next in-frame Met codon is located 149 aa further downstream and has no potential RBS, the first Met is the likely start codon.

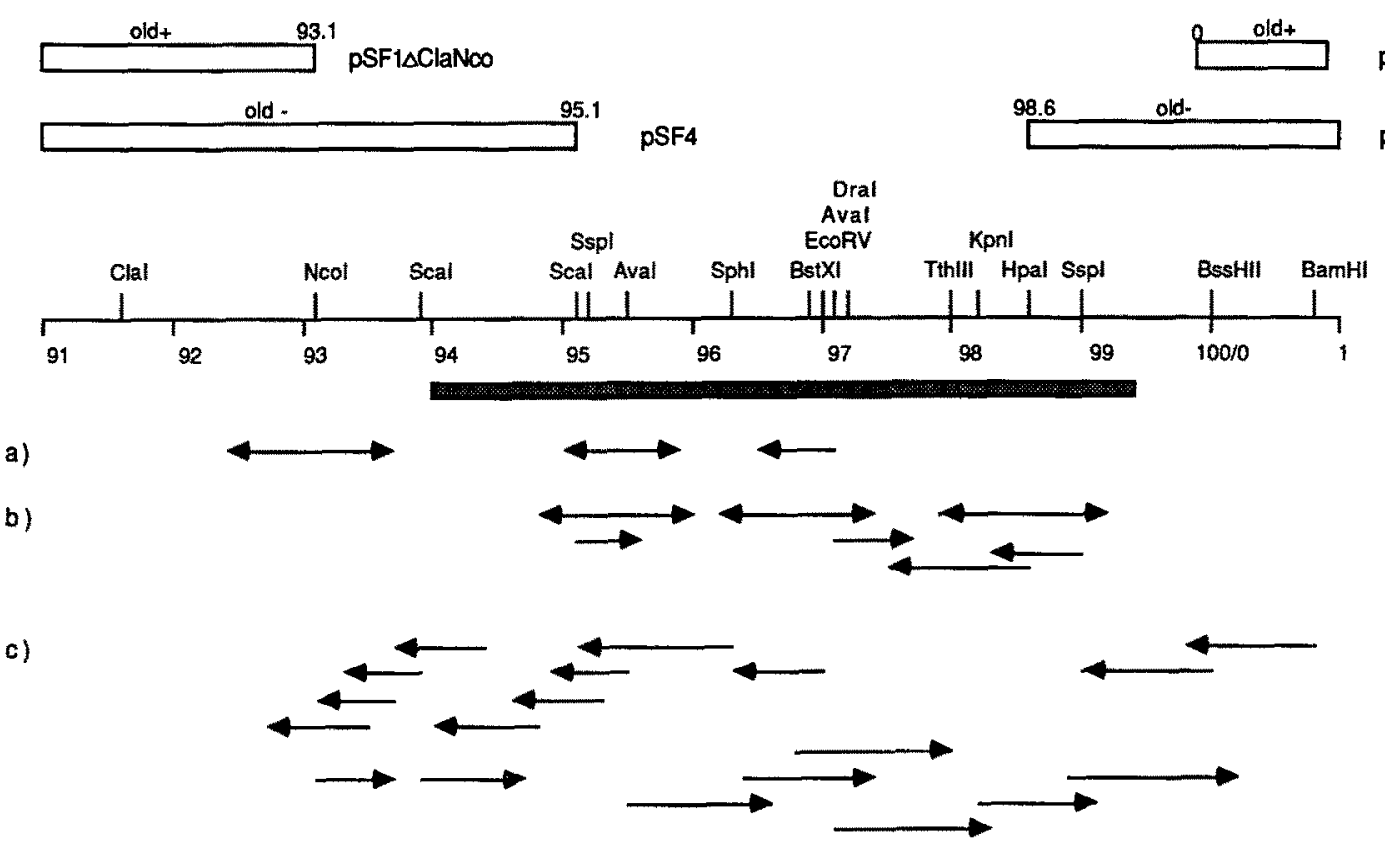

Fig. 2. Physical map of the old region. The open boxes above the line represent the deletions of P2 DNA from pSF1 in the plasmids shown in Fig. 1. The restriction sites used for sequencing are indicated above the line, and their distances in percentage from the left end of the linear $P 2$ genome are indicated below. The total length of P2 is assumed to be $33 \mathrm{~kb}$ (Chattoraj, 1977). The shaded bar below the line shows the location of the old gene. The arrows below the line indicate the regions sequenced using the chemical cleavage method of Maxam and Gilbert (1980) with 5'-end labeled DNA (a) or 3'-end-labeled DNA (b) or the chain-termination method of Sanger et al. (1977) (c). In the Maxam-Gilbert method purified phage DNA was cleaved with appropriate restriction enzymes, and the $3^{\prime}$ termini were labeled with $\left[\alpha_{-}{ }^{32}\right.$ P]ddATP and terminal deoxynucleotidyl transferase or the $5^{\prime}$ termini with $\left[\gamma_{-}{ }^{32} \mathrm{P}\right] \mathrm{ATP}$ and T4 polynucleotide kinase. After cleavage with a second restriction enzyme, the fragments were separated by gel electrophoresis, isolated and chemical sequencing was performed. In the method of Sanger et al. (1977), the DNA was subcloned into pUC18 (Norrander et al., 1983), and when necessary the insert was reduced by digestion with exonuclease III. [ $\alpha{ }_{-}^{35}$ S]dATP and T7 Sequenase were used for the sequencing reaction, using the 'universal' or 'reverse' primers of M13. 
P2 right end 5 - GTGCTTTCCCCGCCTCGCCCGCCCGCTTCACGGGGCGGTTTTAATGCACCTTAATAAAACTAATGAGCCATCAGTaTtTTCCAGTCAAAAGCCAAGCCATATCACAGT

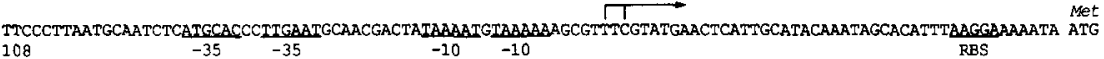

2 Thr Val Arg Leu Ala Ser Val Ser Ile Ser Asn Phe Arg Ser Cys Lys Ser thr Ser Ala Ile Leu Arg Pro Phe thr Ala Leu 227 ACT CGT CTT GCT TCA GTT TCA ATT AGC AAC TTT CGT TCT TGT AAG TCA ACA TCG GCT ATT ITG CGC CCC TIC ACT GCT TTA

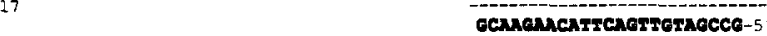

30 Val Giy Tyr Asn Asn Ala Gly Lys Ser Asn Ile Ile Leu Ala Ile tys Trp Leu Lel Asp Gly Ser Leu Ile Ser GIu Ser Asp GTT GGT TAT AAT AAC GCA GGA AAA ICA AAT ATT ATC TTA GCA ATT AAG TGG CTG TTA GAT GGC TCT TTG ATT TCA GAA TCA GA 301

Val Tyr Asp pro thr His pro Val Ser Val Glu Giy Val Ile Gln Gly Ile thr Asp Asp thr teu Ser teu Leu Thr Glu GIu

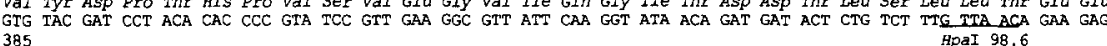
Asn GIn Gin Lys Ile Ala Pro phe ILe Tle Asp Gly Thr Leu Thr Phe Ala Arg Arg Gin Glu phe Asn Lys GIu Thr Giy LyS
AAT CAA CAA AAA ATA GCT CCG TTT ATA ATT GAC GGG ACT CTT ACC TTT GCA AGA AGA CAG GAA TTT AAT AAG GAA ACA GGA AAAA

Ald Lys Lys Ser Leu Asp Val Tyr Asp Gly Thr Thr TrP Lys Lys Asn Pro Gly Gly Ile Asp Gly Ala Ile Ser Asn Ile Phe Ala Iys Lys Ser Leu Asp Val Tyr Asp Gly Thr Thr Trp Lys Lys Asn Pro Gly Gly Ile Asp Gly Ala Ile Ser Asn Ile phe
GCC AAA AAA AGT CTG GAT GTA TAT GAC GGT ACC ACG TGG AAG AAA AAC CCT GGC GGC ATA GAT GGT GCA ATC TCC AAT ATA TI2 553 KpnI 98.2

142 Pro Glu Pro Ile His Ile Pro Ala Met Ser Asp Ale Val Glu Asp Ser Thr Lys Cys Lys Asn Thr Thr Thr Ile Gly Lys Ile

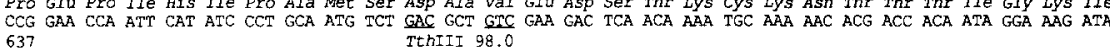
270 Ser Ala Ile vai Ser GIu tle Lys Gln GIu His GIu Glu Lys fhe Ser Lys Asn Ile Ser GIu Ile Gly Lys Tyr Leu Ser Leu Ser Ala Ile Val Ser Glu tle lys Gln Glu His Giu Glu Lys fhe Ser lys Asn Ile Ser Glu Ile Gly bys Tyr Leu Ser
CTT TCC GCA ATT GTT ICT GAA ATA AAA CAA GAA CAC GAA GAA AAA TTT TCA AAA AAC ATA TCA GAA ATA GGT AAA TAT CTT TCT
721

198 is Asn Gly Glu Asn arg Lew Glu Ser Leu Asn Lys Ile Asp Ser Gly Val Asn Lys Lys Val asn Gln phe phe pro Aso Val CAC AAC GGT GAG AAC AGA TTA GAA AGC CTT AAT AAA ATA GAC TCA GGT GTA AAT AAA AAA GTA AAC CAA TTT TTT CCT GAC GTR

226 Ser Vai Lys Leu His phe Pro Thr Pro thr Leu Asp Glu lle Phe Lys Ser Giy thr Leu Lys Vai Phe Glu Ser Arg Giu Asp AGT GTA AAG TTA CAC TTT CCC ACA CCG ACA TTA GAT GAG ATA TICT AAA TCC GGC ACT CTG AAA GTT TTT GAG TCI CGG GAA GA

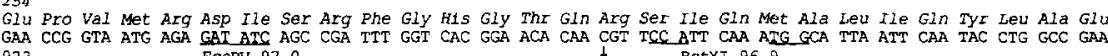
A, olal, His

282 Lys Lys Glu Asn Ser GIu Ser Lys Lys Ser Asn Thr Leu Ile Phe Ile Asp GIu Pro Glu Leu Tyr Leu His Pro Ser Ala ATA AAA AAA GAA AAC AGC GAA TCA AAA AAA TCA AAC ACT TTG ATT TTC ATT GAT GAA CCT GAG TTA TAT TTA CAC CCT TCA GCC 1057

310 Ile Asn Ser Val Arg Glu Ser Leu Val Thr Leu Ser GIu Ser GiY Tyx Gln Val Ile Ile Ser Thr His Ser Ala Ser Met Leu ATt AAT TCT GTC AGA GAA TCA CTT GTC ACA TTA AGT GAA TCA GGG TAT CAG GTT ATA ATA TCA ACT CAC TCA GCC AGT ATG CTT 1141

338 Ala Lys His Ala Ala Asn Ala I1e GIn Val Cys Lys Asp Ser Asn Giy Thr Tie Ala Arg Lys Thr Ile Ser Glu Lys Ile TCT GCA AAG CAT GCA GCA AAT GCG ATT CAG GTT TGT AAG GAT TCT AAT GGA ACC ATA GCA AGG AAG ACT ATA TCT GAA AAA ATC
1225

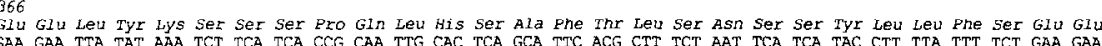
1309

Val Leu Leu Val Glu Gly Lys Thr Glu Thr Asn Val Leu Tyr Ala Lcu Tyr Lys Lys Tlo Asn Giy his Giu Leu Asn Pro Sex GTT TGG CTT GTT GAA GGG AAA ACA GAG ACA AAC GTT CTA TAT GCA CTT TAI AAA AAA ATT AAC GGA CAT GAA CTC AAC CCG AGT
1393
AvaI 95.5

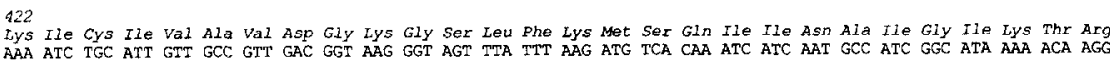
1477

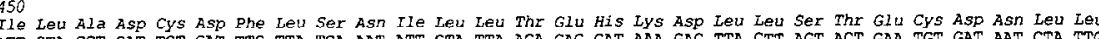

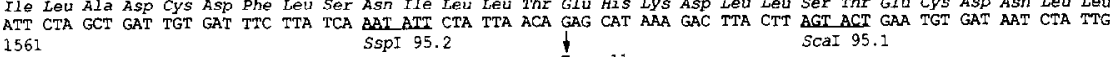
T, ami1 478
Thr Ain tien Tle glu Ser Ile Asn Ser Gly Glu Leu Ser Lel ASn Thr LyS VaI Thr Thr Phe Glu Ser Phe Lys Ser Ile Ser
ACT GCT TTG ATT GAA TCA ATC AAC TCA GGA GAG CTT AGT TTA AAT ACA AAA GTT ACT ACT TTT GAG TCA TTC AAA AGC ATT TCA

506
Ser LYS ASp Phe Ile Lys Ile Cys Asn His Glu Lys The Gln Lys His Ile His Glu Ile His GIn Lys Leu Lys Asp Asn Gly
AGC AAA GAC TTC ATC AAA ATA TGT AAC CAT GAA AAA ACA CAA AAG CAT ATA CAT GAA ATA CAT CAA AAA TTG AAA GAT AAC GGA AGC 2729

534

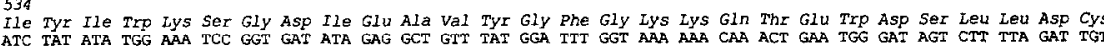
1813

562

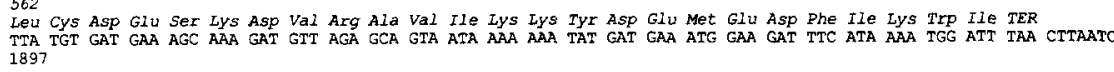

TGATACTATTACAGCACAGRAC:-3

982 SCaI 93

P2 left end 
The ORF is confirmed as that coding for the old gene product by the locations of the old 1 missense mutation and the oldam 11 mutation. The old 1 mutation causes the $\mathrm{C}-1018 \rightarrow \mathrm{A}$ transversion (Fig. 3), with an Arg-269 to His replacement. The oldam11 mutation causes the normal G-1603 to be replaced with a $T$, giving the am codon UAG.

The old gene is expressed constitutively and is therefore expected to have a promoter that is recognized by the $E$. coli RNA polymerase. Between the $\cos$ sequence and the presumed start codon of old there are two promoter-like sequences (Rosenberg and Court, 1979): at nt 126 there is a potential -35 region with the sequence ATGCAC followed by a potential -10 region with the sequence TAAAAT $18 \mathrm{nt}$ further down; at nt 135 there is an alternative -35 region with the sequence TTGAAT followed by a potential -10 region with the sequence TAAAAA $17 \mathrm{nt}$ further down, although the rightward -10 region lacks the highly conserved terminal $\mathrm{T}$ (Fig. 3).

\section{(c) Location of the $5^{\prime}$ termini of the old transcript}

To map the tsp of the old gene transcript, a $5^{\prime}$ labeled synthetic 23-mer, located about $90 \mathrm{nt}$ from the presumed 5' end of the old transcript (Fig. 3) was hybridized to RNA extracted from the P2 lysogenic strain $\mathrm{C}-117$ or as a control from the non-lysogenic strain $\mathrm{C}-1 \mathrm{a}$ and elongated with RT. Using RNA from the P2 lysogenic strain C-117, two major extension products were detected (Fig. 4, lanes 3 and 4). The appearance of bands at these positions is consistent with the tsp of the old mRNA being 46 or $44 \mathrm{nt}$ upstream from the start codon at nt 214, i.e., at nt 168 and 170 , respectively (Fig. 3 ). Thus the -10 and -35 regions located farthest away from the start codon seem to be preferred in the P2-lysogenic strain. Using RNA from cells carrying the old gene on a plasmid (pSF1), we obtained the same extension products (Fig. 4, lanes 11 and 12), but the bands are more intense due to the increased gene dosage.

\section{(d) Levels of the old gene transcript are reduced by} the Escherichia coli pin 3 mutation

Bacterial mutants able to suppress the effects of the old gene are named pin (Ghisotti et al., 1983). To test if the suppression is due to an absence of old mRNA, a primer extension analysis was performed comparing the RNA from pin 3 mutant strains, carrying the old gene on a prophage (C-5024) or on a plasmid (pSF1), using the same $5^{\prime}$ labeled primer as above. As can be seen in Fig. 4, the old transcript is not detectable in strain C-5024 and very reduced in the pin 3 strain carrying plasmid pSF1. Therefore, either old transcription decreased in pin 3 strains or the old mRNA is rapidly degraded.

\section{(e) The effect of the pin3 mutation is suppressed by} the wild-type $\arg U$ gene

The pin 3 mutation maps at $12.2 \mathrm{~min}$ on the $E$. coli map (Ghisotti et al., 1983). This position corresponds to that of $\arg U$, which encodes the precursor of a tRNA ${ }^{\text {Arg }}$ that reads the rare codon AGA and probably also the rare codon AGG (Garcia et al., 1986). Thus we tested the effect of wt $\arg U$ gene (plasmid pBR1824; Mullin et al., 1984) on E. coli pin 3 strain C-5024. This arg $U$ plasmid restored the ability of the old gene to interfere with phage $\lambda$ growth. Inspection of the old gene sequence shows that the AGA codon appears six times (103, 104, $203,258,314,570$ ), and the AGG codon appears twice $(358,449)$. The other Arg codons, which begin with $\mathrm{CG}$, are used only six times $(4,14,24,251,262$, 269). Thus the majority of Arg codons are those rare ones read by argU tRNA, whereas these codons represent only $4 \%$ of the Arg codons in $E$. coli (Aota et al., 1988). Grosjean and Fiers (1982) suggested that the appearance of rare codons slows down translation and Spanjaard and Van Duin (1988) showed that the sequence AGG AGG causes ribosomal frameshifting. We suppose that, when the

Fig. 3. Nucleotide sequence of the $\mathrm{P} 2$ wt old gene region and deduced aa sequence. The proposed promoters are indicated with the underlined -10 and -35 regions. The location of the $5^{\prime}$ termini $(t s)$ of the old gene transcript is indicated by the arrow above the line. The restriction sites used for the nt sequence determination are underlined, along with the nt and aa changes resulting from the old 1 and 11 mutations. The primer used for the primer extension analysis is shown in outlined letters below the line. The GenBank accession number for this sequence is $\mathrm{M} 27131$. P2 oldam11 was isolated by screening for a phage that would make plaques on $E$. coli rec $B$ sup ${ }^{\circ}$ but not on $E$. coli recB sup F. These bacterial strains are WM1200 hsdR araDAara-leuAlac galU galK rpsL recB recC [a derivative of MC1061 of Casadaban and Cohen (1980)], and WM1200 carrying supF on the plasmid pGFY $\pi$ AN7 (Lutz et al., 1987; H.V. Huang and J. Schwedock, unpublished). 


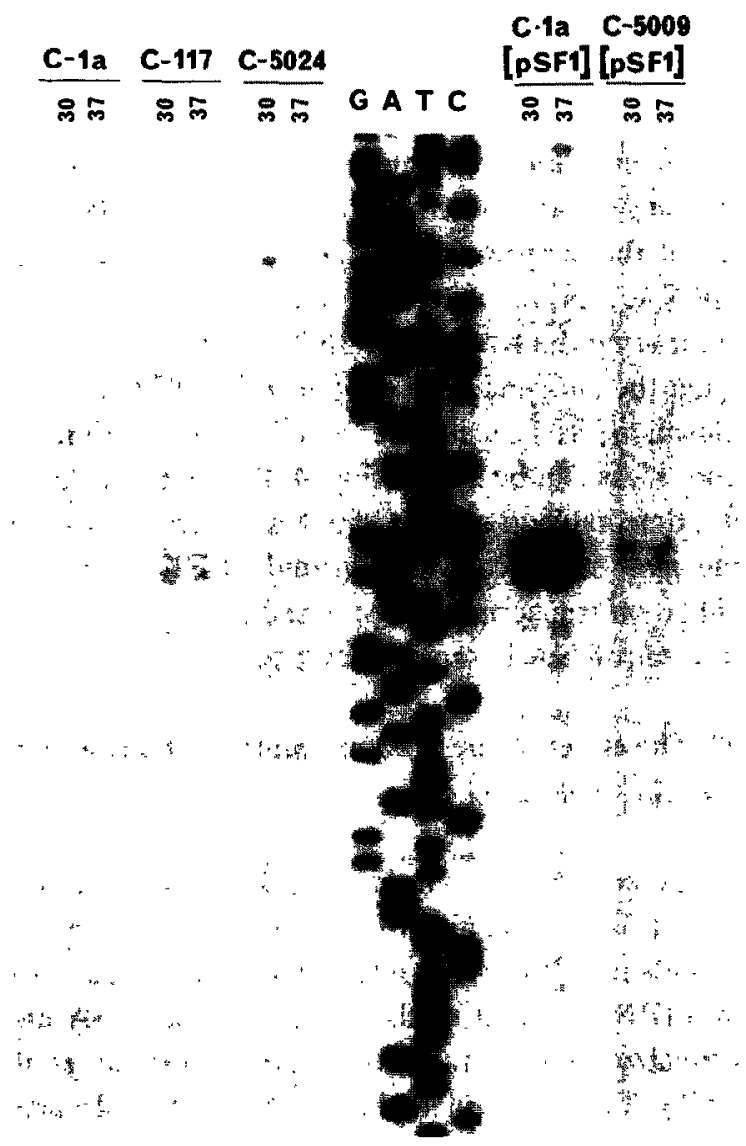

Fig. 4. Analysis of the old gene transcript by primer extension. RNA was extracted from the cells listed above the respective lane, hybridized to the 5 -labeled primer (Fig. 3) at the temperatures (in ${ }^{\circ} \mathrm{C}$ ) indicated above the lanes, extended by RT and analyzed by gel electrophoresis. $\mathrm{G}, \mathrm{A}, \mathrm{T}$, and $\mathrm{C}$ indicatc the respective sequencing reactions (Fig. 2). $\mathrm{C}-1 \mathrm{a}$ is a prototrophic $E$. coli C strain (Sasaki and Bertani, 1965). C-117 is C-1a lysogenized with P2 (Bertani, 1968). C-5009 is a pin3 (Ghisotti et al., 1983) derivative of C-1a and C-5024 is a P2 lysogenic derivative of C-5009. Total RNA was extracted from $20-\mathrm{ml}$ cultures containing $4 \times 10^{8}$ bacteria per $\mathrm{ml}$ as described by Hagen and Young (1978). The primer (Fig. 3) was labeled at the $5^{\prime}$ termini with ${ }^{32} \mathrm{P}$ as follows: $50 \mathrm{pmol}$ of the oligo was incubated with 10 units of $\mathrm{T} 4$ polynucleotide kinase and $200 \mu \mathrm{Ci}\left[\gamma-{ }^{32} \mathrm{P}\right] \mathrm{ATP}$ ( $3000 \mathrm{Ci} / \mathrm{mmol}$ ), using the reaction conditions recommended by the supplier (Promega). Polynucleotide kinase was inactivated by incubation at $65^{\circ} \mathrm{C}$ for $15 \mathrm{~min}$, and the labeled oligo was precipitated with ethanol until no radioactivity could be detected in the supernatant after centrifugation. The 5' end-labeled oligo was thereafter used to prime synthesis as follows: $5 \mu \mathrm{g}$ RNA was incubated with $5 \times 10^{-2}$ pmol $5^{2}$ end-labeled oligo in $40 \mathrm{mM}$ Pipes pH 6.4/0.4 M NaCl/1 mM EDTA $/ 80 \%$ formamide in a total volume of $30 \mu \mathrm{l}$ at $30^{\circ} \mathrm{C}$ or $37^{\circ} \mathrm{C}$ overnight. The primed RNA was ethanol-precipitated, redissolved in $10 \mu \mathrm{l} 2 \times \mathrm{AMV}$ buffer $\left(100 \mathrm{mM}\right.$ Tris. $\mathrm{HCl}$ pH $8.3 / 16 \mathrm{mM} \quad \mathrm{MgCl}_{2} / 60 \mathrm{mM}$ $\mathrm{KCl} / 2 \mathrm{mM}$ DTT) and $4 \mu \mathrm{dNTP} \mathrm{mix}$ (containing each of the four dNTPs at $10 \mathrm{mM}$ ), $0.5 \mu 1 \mathrm{RNasin}(40$ units $/ \mu \mathrm{l}), 4.5 \mu 1 \mathrm{H}_{2} \mathrm{O}$ and $1 \mu \mathrm{I} \mathrm{AMV} \mathrm{RT} \mathrm{(10} \mathrm{units/ \mu 1)} \mathrm{were} \mathrm{added} \mathrm{and} \mathrm{the} \mathrm{sample} \mathrm{was}$ ribosome reaches the two tandem AGA codons at positions 103 and 104 in the old gene, translation stalls or shifts frame and the old mRNA is degraded.

\section{(f) Identification of the Old protein and comparison to other proteins}

To identify the Old protein we performed twodimensional gel electrophoresis of proteins made in $E$. coli strain $\mathrm{C}$ carrying either $\mathrm{pSF} 1$ or $\mathrm{pSF} 5$, which carries the oldam 11 allele (Fig. 5). We identified a basic protein that is present in cells carrying pSF1 $\left(\right.$ old ${ }^{+}$) but which is absent in cells carrying pSF5 (Fig. 5). The mobility of this protein during electrophoresis on SDS-polyacrylamide gels is between the mobilities of the GroEL protein $(63 \mathrm{kDa})$ and the DnaK protein $(69 \mathrm{kDa})$. Its electrophoretic position suggests that the Old protein bands at about $65 \mathrm{kDa}$, in agrecment with the $M_{\mathrm{r}} 65373$ deduced from the nt sequence. The protein that we have identified as the old gene product is among the basic proteins found in $E$. coli, having a pI of about 7 .

Gibbs et al. (1983) assigned the P2 Old protein an $M_{\mathrm{r}}$ of 29500 . However, the old gene is followed by an ORF that might code for a $27-\mathrm{kDa}$ protein (E.H.-L., unpublished). Thus, the protein found by Gibbs et al. (1983) using a deletion mutation might be the product of this ORF.

We compared the P2 Old polypeptide sequence with the proteins in the EMBL Swissprotein database, using the FASTP program (Lipman and Pearson, 1985) but found no significant similarities.

\section{(g) The mechanism of Old protein action}

The $\operatorname{rec} B$, rec $C$, and $\operatorname{rec} D$ genes code for exonuclease V (ExoV), a complex enzyme that has multiple activities and which plays an important role in homologous genetic recombination and DNA repair in $E$. coli (Amundsen et al., 1986). Infection of $E$. coli

incubated at $42^{\circ} \mathrm{C}$ for $1 \mathrm{~h}$. The sample was precipitated with ethanol, dried and dissolved in formamide-dye buffer described by Maxam and Gilbert (1980). Dideoxy sequencing ladders were generated using the $5^{\prime}$ end-labeled oligo hybridized to the $99-100 \%$ region of $\mathrm{P} 2$ DNA cloned into pUC18 and $\mathrm{T} 7$ Sequenase using standard conditions. All samples were heated to $90^{\circ} \mathrm{C}$ for $3 \mathrm{~min}$, chilled on ice and loaded onto an $8 \%$ polyacrylamide/ $7 \mathrm{M}$ urea sequencing gel. 
A

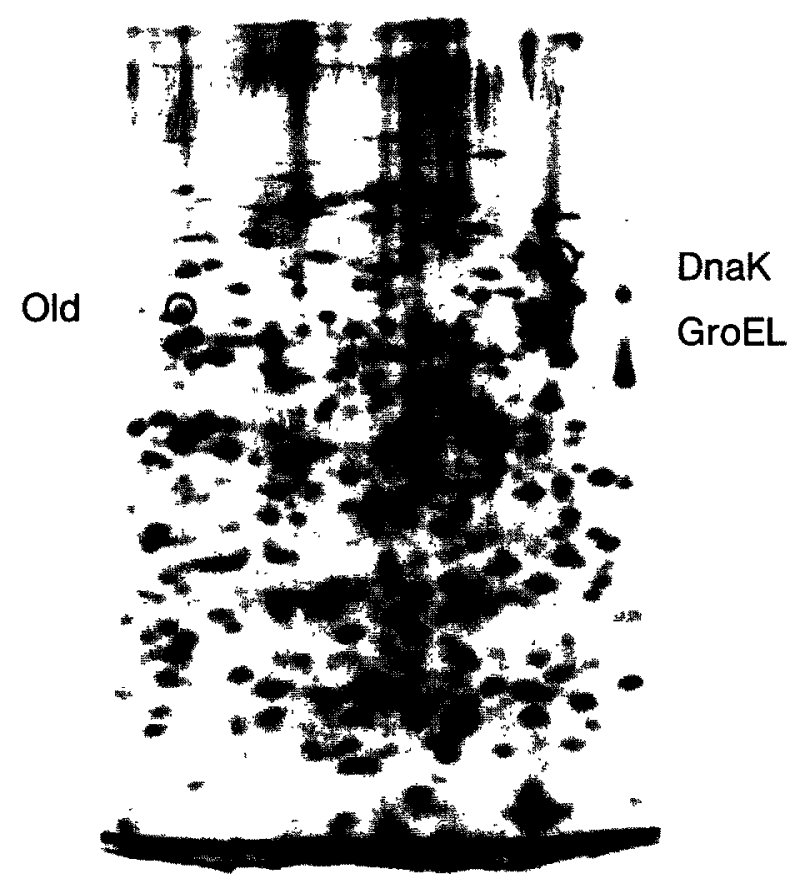

B

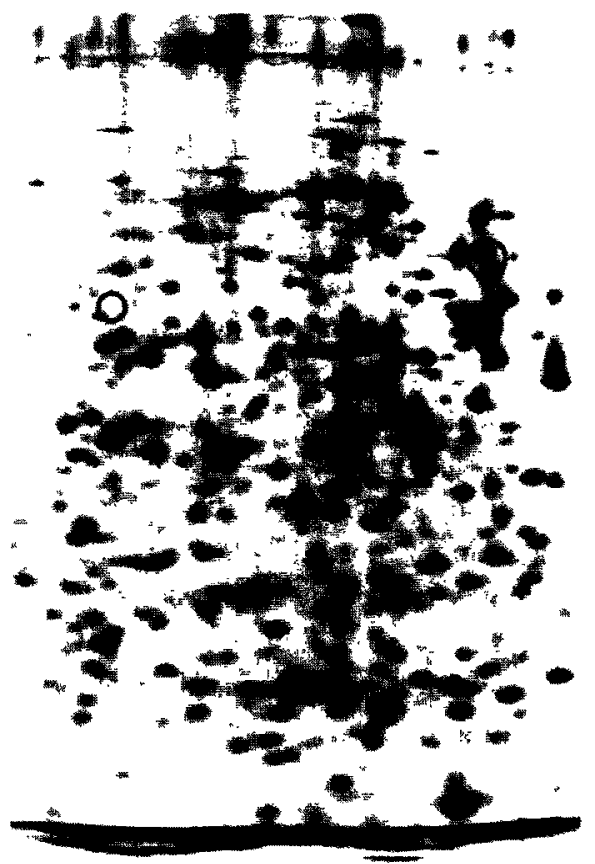

Fig. 5. Identification of the $\mathrm{P} 2$ old gene product synthesized in vivo: a comparison of the two-dimensional gel profiles of $E$. coli $\mathrm{C}-1 \mathrm{a}$ carrying pSF1 (old ${ }^{+}$, left) or pSF5 (oldamll, right). The circles denote the positions of the proteins encoded by genes old, groEL $\left(M_{\mathrm{r}}\right.$ 62883) and dnaK ( $M_{\mathrm{r}} 69121$; upper of the two major spots). Exponential growth phase cultures were labeled for 1 min with $\left[{ }^{35}\right.$ S $]$ methionine (Hoyt et al, 1982). Cells were harvested, lysed and subjected to two-dimensional gel electrophoresis (O'Farrell, 1975).

lacking ExoV by P2 old ${ }^{+}$causes cell death (Sironi, 1969; Sironi et al., 1971). Bacteriophage $\lambda$ is unable to grow on $\mathrm{P} 2$ old ${ }^{+}$-lysogenic strains because the $\lambda$ gam gene product inactivates ExoV, making the cells into $\mathrm{RecBCD}-$ phenocopies that are then killed by the P2 Old protein (Sakaki et al., 1973). The killing of $E$. coli by the Old protein has not been studied in recB or recC cells but only in P2-lysogenic cells infected by phage $\lambda$ (Brégégère, 1974). Under these conditions protein synthesis stops and tRNA is functionally inactivated. The absence of functional tRNA stops translation, presumably causing $\lambda$ mRNA to be degraded.

To begin studying the activities of the Old product, we can modify Brégégère's system and study old function in the absence of phage $\lambda$, i.e., in an $E$. coli $r e c B$ strain where the old gene can be expressed from a plasmid. In cells lacking ExoV, synthesis of the Old protein would need to be controlled. This could be accomplished by cloning the old gene downstream from an inducible promoter that can be tightly repressed. Experimentation with this system will allow us to determine whether any other genes of P2 or $\lambda$ are necessary for the phenomena observed by Brégégère (1974).

A specific explanation of Brégégère's findings is that the Old protein activates or is a nuclease that attacks tRNA from the $3^{\prime}$ end, removing the accessible CCA. Such a RNase would be similar to Exol, which removes 5'-phosphoryl mononucleotides from the $3^{\prime}$ end of single-stranded DNA (Lehman and Nussbaum, 1964). Mutations that inactivate the Exol-encoding gene (xon $A$ ) partially restore the recombination proficiency of $\operatorname{rec} B$ and $\operatorname{rec} C$ strains and cause the cells to grow faster (Kushner et al., 1972). Thus, Exol is deleterious for E. coli recB mutants, and if the P2 Old protein had an Exo I-like activity it might be expected to kill recB mutant cells. To test these hypothetical enzyme activities of the old product, we can assay an $E$. coli strain that has been deleted for the xonA gene and which carries the old ${ }^{+}$ gene on a plasmid. 


\section{ACKNOWLEDGEMENTS}

This work was supported by grants 72 and 7078 from the Swedish Medical Research Council; by research grant AI-08722 from the National Institute of Allergy and Infectious Diseases, National Institutes of Health; and by a Biotechnology Training Grant from the State of California. D.M.K. is an Investigator in the Howard Hughes Medical Institute at Ann Arbor, MI. The primer for analysis of the mRNA $t s p$ was the generous gift of KabiGene. Strains C-5009 and C-5024 were a generous gift from Gianpiero Sironi. Thanks are due to Steven Finkel for characterizing some of the plasmids described; to Conrad Halling for helpful discussions on deletion analysis and analysis of the sequence data, and to Julie Schwedock for assistance in the isolation of P2 old amber mutants.

\section{REFERENCES}

Amundsen, S.K., Taylor, A.F., Chaudhury, A.M. and Smith, G.R.: recD: the gene for an essential third subunit of exonuclease V. Proc. Natl. Acad. Sci. USA 83 (1986) 5558-5562.

Aota, S.-i., Gojobori, T., Ishibashi, F., Maruyama, T. and Ikemura, T.: Codon usage tabulated from the GenBank genetic sequence data. Nucleic Acids Res. 16 (1988) r315-r402.

Bertani, L.E.: Abortive induction of bacteriophage P2. Virology 36 (1968) 87-103.

Bolivar, F., Rodriguez, R.L., Greene, P.J., Betlach, M.C., Heyneker, H.L., Boyer, H.W., Crosa, J.H. and Falkow, S.: Construction and characterization of new cloning vehicles, II. A multipurpose cloning system. Gene 2 (1977) 95-113.

Brégégère, F.: Bacteriophage $P 2-\lambda$ interference: inhibition of protein synthesis involves transfer RNA inactivation. J. Mol. Biol. 90 (1974) 459-467.

Casadaban, M.J. and Cohen, S.N.: Analysis of gene control signals by DNA fusion and cloning in Escherichia coli. J. Mol. Biol. 138 (1980) 179-207.

Chattoraj, D.K.: Genetic and physical map of bacteriophage P2. In Bukhari, A.I., Shapiro, J.A., Adhya, S.L. (Eds.), DNA Insertion Elements, Plasmids and Episomes. Cold Spring Harbor Laboratory, Cold Spring Harbor, NY, 1977, pp. 733-736.

Finkel, S., Halling, C. and Calendar, R.: Selection of lambda $\mathrm{Spi}^{-}$transducing phages using the $\mathrm{P} 2$ old gene cloned onto a plasmid. Gene 46 (1986) 65-69.

Garcia, G.M., Mar, P.K., Mullin, D.A. and Walker, J.R.: The E. coli dna $Y$ gene encodes an arginine transfer RNA. Cell 45 (1986) 453-459.

Ghisotti, D., Zangrossi, S. and Sironi, G.: An Escherichia coli gene required for bacteriophage $\mathrm{P} 2-\lambda$ interference. J. Virol. 48 (1983) 616-626.
Gibbs, W., Eisen, H. and Calendar, R.: In vitro activation of bacteriophage $P 2$ late gene expression by extracts from phage P4-infected cells. J. Virol. 47 (1983) 392-398.

Grosjean, H. and Fiers, W.: Preferential codon usage in prokaryotic genes: the optimal codon-anticodon interaction energy and the selective codon usage in efficiently expressed genes. Gene 18 (1982) 199-209.

Hagen, F.S. and Young, E.T.: Effect of RNasellI on efficiency of translation of bacteriophage T7 lysozyme mRNA. J. Virol. 26 (1978) 793-804.

Hoyt, M.A., Knight, K.M., Das, A., Miller, H.I. and Echols, H.: Control of phage $\lambda$ development by stability and synthesis of cII protein: role of the viral cIII and host $h f L A, \operatorname{him} A$ and himD genes. Cell 31 (1982) 565-573.

Jacobsen, H., Klenow, H., and Overgaard-Hansen, K.: The $\mathrm{N}$-terminal amino acid sequences of DNA polymerase I from $E$. coli and the large and small fragments obtained by limited proteolysis. Eur. J. Biochem. 45 (1974) 623-627.

Karu, A.E., Sakaki, Y., Echols, H. and Linn, S.: The $\gamma$ protein specified by bacteriophage $\lambda$. Structure and inhibitory activity for the recBC enzyme of Escherichia coli. J. Biol. Chem. 250 (1975) 7377-7387.

Kushner, S., Nagaishi, H. and Clark, A.J.: The indirect suppression of recB and recC mutations by exonuclease I-deficient strains. Proc. Natl. Acad. Sci. USA 69 (1972) 1366-1370.

Lehman, I.R. and Nussbaum, A.: The deoxyribonucleases of $E$. coli, V. On the specificity of exonuclease I. J. Biol. Chem. 239 (1964) 2628-2636.

Lindahl, G., Sironi, G., Bialy, H., and Calendar, R.: Bacteriophage lambda: abortive infection of bacteria lysogenic for phage P2. Proc. Natl. Acad. Sci. USA 66 (1970) 587-594.

Lipman, D.S. and Pearson, W.R.: Rapid and sensitive protein similarity searches. Science 227 (1985) 1435-1441.

Lutz, C.T., Hollifield, W.C., Seed, B., Davie, J.M. and Huang, H.V.: Syrinx 2A: an improved $\lambda$ phage vector designed for screening DNA libraries by recombination in vivo. Proc. Natl. Acad. Sci. USA 84 (1987) 4379-4383.

Maxam, A. and Gilbert, W.: Sequencing end-labeled DNA with base-specific cleavages. Methods Enzymol. 65 (1980) 499-560.

Mullin, D.A., Garcia, G.M. and Walker, J.R.: An E. coli DNA fragment 118 base pairs in length provides $d n a Y^{+}$complementing activity. Cell 37 (1984) 669-674.

Murray, N.: Phage lambda and molecular cloning. In Hendrix, R.W., Roberts, J.W., Stahl, F.W. and Weisberg, R.A. (Eds.), Lambda II. Cold Spring Harbor Laboratory, Cold Spring Harbor, NY, 1983, pp. 395-432.

Norrander, J., Kempe, T. and Messing, J.: Construction of improved M13 vectors using oligodeoxynucleotide-directed mutagenesis. Gene 26 (1983) 101-106.

O'Farrell, P.: High resolution 2-dimensional electrophoresis of proteins. J. Biol. Chem. 250 (1975) 4007-4021.

Rosenberg, M. and Court, D.: Regulatory sequences involved in the promotion and termination of RNA transcription. Annu. Rev. Genet. 13 (1979) 319-353.

Sakaki, Y., Karu, A.E., Linn, S. and Echols, H.: Purification and 
properties of the $\gamma$-protein specified by bacteriophage lambda: an inhibitor of the host $\operatorname{recBC}$ recombination enzyme. Proc. Natl. Acad. Sci. USA 70 (1973) 2215-2219.

Sanger, F., Nicklen, S. and Coulson, A.R.: DNA sequencing with chain-terminating inhibitors. Proc. Natl. Acad. Sci. USA 74 (1977) 5463-5467.

Sasaki, I. and Bertani, G.: Growth abnormalities in Hfr derivatives of Escherichia coli strain C. J. Gen. Microbiol. 40 (1965) 365-376.

Sironi, G.: Mutants of Escherichia coli unable to be lysogenized by the temperate bacteriophage P2. Virology 37 (1969) 163-176.

Sasaki, I. and Bertani, G.: Growth abnormalities in Hfr derivatives of Escherichia coli strain C. J. Gen. Microbiol. 40 (1965) 365-376.

Sironi, G.: Mutants of Escherichia coli unable to be lysogenized by the temperate bacteriophage P2. Virology 37 (1969) 163-176.
Sironi, G., Bialy, H., Lozeron, H.A. and Calendar, R.: Bacteriophage $P 2$ : interaction with phage $\lambda$ and with recombinationdeficient bacteria. Virology 46 (1971) 387-396.

Spanjaard, R.A. and Van Duin, J.: Translation of the sequence AGG-AGG yields $50 \%$ ribosomal frameshift. Proc. Natl. Acad. Sci. USA 85 (1988) 7967-7971.

Steitz, J.A. and Jakes, K.: How ribosomes select initiator regions in mRNA: base pair formation between the $3^{\prime}$-terminus of 16S rRNA and the mRNA during initiation of protein synthesis in E. coli. Proc. Natl. Acad. Sci. USA 72 (1975) 4734-4784.

Zissler, J., Signer, E. and Schacfer, F.: The role of recombination in growth of bacteriophage lambda, I. The gamma gene. In Hershey, A.D. (Ed.), The Bacteriophage Lambda. Cold Spring Harbor Laboratory, Cold Spring Harbor, NY, 1971, pp. $455-468$. 